\section{The Politics of Truancy in 1992}

\section{LIZ GORDON}

$\mathrm{D}$

uring April and May 1992, the problem of school truancy received headline treatment in the media. Amongst the claims made were that the rate of school truancy had increased markedly since the Tomorrow's Schools reforms, that individual schools had neither the time nor the resources to police truancy and that students were "slipping through the cracks" opened up by the reform process. As a result of the media attention, the Ministers of Education and Social Welfare brought out a new policy statement on truancy in mid-1992.

The issue of truancy encapsulates many of the broader problems that schools are encountering as a result of the reform process. Although truancy is, perhaps, the oldest educational problem in New Zealand, a number of factors have combined to make it also a new problem; one that has required new responses. These factors, in brief, are as follows:

1. The restructuring of the school system has devolved the responsibility for dealing with truancy to boards of trustees;

2. Despite a greatly increased overall retention rate to the senior school, there is some evidence that a small group of relatively young students continue to be alienated from the schooling system, and are persistent truants - and that this alienation may be increasing (Taylor, 1992);

3. The raising of the school leaving age to 16 in 1993 is likely to increase the level of truancy, as some young people are prevented from leaving school; and

4. The new trend of social conservatism, evident in the discourse of parental responsibility, is tending to blame individual families for school truancy.
In a sense, then, the issue of truancy is simply one aspect of a much broader movement in education and throughout the state. Elements of the marketisation of education and its effects are clearly evident: the devolution of state responsibility, the increasing gap between rich and poor (or, in this case, school stayers and the disaffected), and the social authoritarianism which has become a characteristic of the National Government. At the same time, however, the contradictions of the market are also visible in this policy. On the one hand, the state wishes to maintain, and even extend, compulsory schooling, whilst on the other hand the responsibility for non-compliance is firmly vested in the parents, or consumers of education.

Above all, truancy is a social issue. This paper will show that research studies in New Zealand demonstrate that Maori rates of truancy are comparatively high. Truancy is also high amongst the pakeha working class. New methods of dealing with truancy, then, impact most heavily on these groups. The authoritarian "blame the victim" responses being advocated by the state are thus a direct attack on the least powerful groups in our schooling system.

The first part of this paper briefly examines the background to truancy in New Zealand schools, up to and including the changes and effects of the 1989 Education Act, which devolved responsibility for truancy to boards of trustees. The second section examines issues that arise from the new policy, which revolve around the changing role of the state and its effects. The final section examines political responses to truancy in 1992 within the economic and social context, focussing on the effects of the new "rules". The conclusion will consider the educational implications of the current truancy problem.

\section{Historical Background}

The issue of truancy has been a major problem for the state ever since the 1877 Education Act made schooling compulsory. Roy Shuker (1987, p. 81) notes that:

... the state's intervention in this sphere was far from a straightforward and uncontested issue. As Katz has observed: "The critical decisions about school attendance policy rested on contentious assumptions about the obligations, limitations and style of the state and its relationship to essentially private groups such as the family" (Katz, 1972, p. 433). 
This applied to issues such as the degree of coercion which should be applied to bring truant children into school and the possible application of sanctions against parents who refused to send their children to school. In this last respect patterns of school attendance reflect changing family attitudes towards formal education, and the relationship of these to social class background and the changing economic context (Shuker, 1987, p. 81).

In the late nineteenth century, the problem of ensuring attendance at school was a major one for educationists. Two School Attendance Acts were passed in 1894 and 1901, aiming to enforce the compulsory nature of schooling. However, McKenzie argues that these Acts merely underlined what was already a growing trend towards staying on at school (McKenzie, 1982). This trend was probably caused by the decline of child labour due to protective legislation, the growth in real schooling opportunities and the increasing need for educational qualifications in order to gain work (ibid).

As school attendance increased, those who remained away from school, a dwindling minority, were identified as "truants". Throughout most of this century, truancy appears to have been an endemic but relatively minor problem in New Zealand schools. Although attendance regulations have been modified from time to time (e.g., in 1951, due to the increase in secondary school attendance), the issue seems to have received little attention. For example, a 1966 Department of Education survey found that truancy was seen as not "a serious national problem". Despite this, Jensen, in a re-examination of the figures from the 1966 survey, noted that "truancy is rather more common than might be expected ... there is probably a significant problem of Maori truancy ... and it is quite possible that in some particular schools and areas there is a problem of serious truancy amongst both Maori and non-Maori pupils" (quoted in Department of Education, 1982, p. 5).

In 1982 a further, very detailed, survey of truancy was undertaken by the Department of Education. This survey confirmed that, amongst certain groups, there was a significant problem of truancy. The 1982 survey found that, in general, schools used external agencies to deal with problems of persistent truancy. These included the visiting teacher, social welfare officers, youth aid officers, attendance officers and other services. A key role was played by attendance officers, who were employed by Education Boards. It appears that the actual service offered by attendance officers varied greatly between districts, depending on the skills of the officer (Berwick-Emms, 1986). These officers were used most frequently for the purpose of prosecuting parents for the continued absence of children, although they also played an important role in tracing students as they moved from one school to another.

From 1877 to 1989, then, the responsibility for dealing with serious cases of truancy was taken by agencies outside of schools. Schools have been required for many years to have a system for monitoring attendance. The 1989 Education Act, however, devolved to boards of trustees the further requirement of ensuring the attendance of students, and of prosecuting the parents or caregivers of a truant child.

The Ministry of Education, in a 1991 research report (Donn, Bennie and Kerslake, 1991), noted:

The dissolution of education board offices and the role of the truancy officer now means that there is no central point from which children who may fail to enrol at school or re-enrol on changing schools can be investigated, or to which those who are chronic absentees can be referred for further action. The current legislation governing truancy has been criticised by schools, their boards and also the media as being ineffective and unworkable. The boards of trustees are now responsible for ensuring that all reasonable steps are taken to ensure that children enrolled in their school attend when it is open. Under section 31 of the Education Act 1989, a board may appoint an attendance officer for the school it administers. Attendance officers may also be shared by several schools thereby reducing costs. Funding for attendance officers must come from schools' bulk funding (p. 3).

The criticism noted by this report in 1991 continued to intensify in 1992, and led finally to the release of a joint policy statement by the Ministers of Education and Social Welfare. This document re-affirmed the policy of devolution. The criticism of a lack of a central structure for coordinating truancy policy was met by a strong assertion that the responsibility for truancy was a parental one, and should be dealt with as such. In other words, truancy was a problem of family breakdown, not of the state. 


\section{The Reform of Education and the Problem of Truancy}

The truancy issue, as experienced in 1992, actually involved five identifiable, but interlinked, elements. These will be dealt with in turn in this section. The first is the perennial issue of compulsory education, and whether (and to what extent) the state should intervene in people's private lives. The second is the raising of the school leaving age to 16 years in 1993, which will tend to accentuate the problem of truancy amongst those groups who already have comparatively high levels of it. The third issue is apparently administrative, but actually points to a major contradiction within the schooling system: that of board of trustee management of truancy. The fourth point is the relationship of social and educational inequalities to truancy, and the likelihood that an increase in the former will lead to an increase in the latter. The final area I will discuss is the new state response to truancy; the issue of parental responsibility.

\section{Compulsory attendance}

The need for compulsory attendance at school has been a central facet of state schooling in New Zealand since 1877. The justification for compulsion has varied over time, and across political parties. In general, such justifications have related either to the need for an educated workforce, with arguments usually pointing to the economic success of other nations which have "better" schooling systems, or to the need for an educated population to make intelligent democratic choices.

Because compulsory attendance is a state requirement, various agencies of the central state have always, until recently, taken responsibility for enforcing it. However, in the 1989 Education Act such responsibility was devolved, along with most other school operations, to individual boards of trustees. Certain state agencies, in particular Social Welfare, are able to intervene in truancy cases, but the responsability of bringing parents to account initially lies heavily with trustees.

The devolution of this crucial function of ensuring attendance to boards of trustees raises some questions about the commitment of the neo-liberal state to compulsory education. The 1987 Treasury brief on education, for example, was less than enthusiastic about compulsion, arguing in fact that in educational or economic terms, "there can be no case for compelling attendance at formal educational institutions" (1987, p. 131). Compulsory attendance, Treasury argues, encourages "resignation of responsibility by the individual's family", weakens "the growth of responsibility by the individual" and distorts "the decision making processes" of the individual (p. 132). The brief concludes that, in order to avoid these effects, government intervention to ensure school attendance should be limited to the provision of information about the benefits of education.

The issue of compulsory education encompasses both the major schools of thought of neo-liberalism. For the followers of Hayek, the need is to reduce state intervention, and indeed the size of the state, in order to make the market "free". For Nozick, choice is a fundamental right which is removed from people by the actions of the state (Ball, 1990; Marshall, Peters and Smith, 1991). Thus both would necessarily oppose compulsory education. It is therefore not surprising that Treasury argued against it.

This is not to say that either the Labour or National governments have accepted Treasury's arguments. It is, however, important to acknowledge that the withdrawal of the central state has caused some cracks to appear in attendance policy, and in dealing with truancy. For example, if a young person leaves intermediate school and fails to enrol at a secondary school, there is now no system within education to ensure attendance; simply, no one will know that they are missing unless they come to the attention of other authorities such as the Police or Social Welfare. Also, the commitment of trustees to policing truancy, when there are so many other pressing problems for them to deal with, may be low. This point, and the government's response to it, will be discussed below.

It is therefore questionable whether the state's commitment to ensuring compulsory attendance is very strong at the present time. On the other hand, the raising of the school leaving age to 16 next year would seem to indicate such a commitment.

\section{Staying until 16}

By 1992, most young people were staying on at school until age 16. Therefore, the increase in the leaving age is, in part, a reflection of existing practices of the majority. Indeed, as in all previous increases in the school leaving age, the regulation has followed, rather than led, existing practices. In $1980,57.8 \%$ of non-Maori stayed at school until Form 6. By 1991 this had risen to $82 \%$. However, the picture is rather different when we consider Maori retention rates. In 1980, 22.1\% of 
Maori students stayed until Form 6, and by 1991 this had increased significantly to $54.9 \%$, although this is still only just over half of the Maori school population (Research and Statistics Division, 1992; Department of Statistics, 1991).

There are, in fact, quite different patterns of attendance for Maori and non-Maori pupils in secondary schools. Figures for 1990 show that $40 \%$ of those leaving from the third form and $43 \%$ of fourth form leavers were Maori - this group probably constituting the majority of those leaving school before the age of 16 (Ministry of Education, 1991). Thus the effects of the raising of the school leaving age will impact most heavily on Maori pupils.

It is boards of trustees who will have the responsibility of enforcing the new policy on school leaving age. Those schools with a high Maori roll will thus have far more to do than schools with few or no Maori pupils. This, however, is just one of many problems that boards face in administering attendance policy.

\section{Boards of trustees}

The legal position of boards of trustees in relation to truancy is laid out in the 1992 report as follows:

Boards of trustees are legally required (s. 25 Education Act 1989) to take all reasonable steps to ensure students enrolled in its schools attend the school whenever it is open. They have certain powers to assist them in this requirement (s. 31 Education Act 1989).

The Ministry of Education funds boards of trustees through their operational activity grant, part of which can be used to assist them in carrying out their responsibilities under Section 31, Education Act 1989. The Ministry is also responsible for the development of policy and research in the area of primary and secondary school enrolment and attendance (Ministers of Education and Social Welfare, 1992, p. 3).

The devolution of responsibility for attendance and truancy to boards of trustees raises almost insu perable problems. It is a national policy, but one that has to be administered at the school level; not, by far, the most efficient place for it. Truancy is clearly related to the social and cultural background of students; thus, those schools with large numbers of working class, Maori and Pacific Island students face far higher levels of truancy than white middle class schools. As a result, those schools which are already stretched for resources will have to spend most time policing truancy. This again detracts from the educational functions of school.

The case of Avalon Intermediate, reported in the Evening Post (Tamati, 23 September 1992), demonstrates that schools can respond to the truancy problem. With a mixture of supporting parents, having a strict policy on attendance, following up absences and being prepared to prosecute parents, this school has reduced the level of truancy by 90 percent. In commenting on this success, the school attendance officer nevertheless noted that it had a price:

My salary would have been paid anyway. But in real terms, it's taking me away from other things. I believe that the philosophy of ... the primacy of market forces is nothing more or less than rampant Victorian opportunism. It is dragging us back to the days of survival of the fittest and that's what marketism is - fit companies rise and weak companies fall. That's fine when it applies to companies but when you apply it to 11-year-old children somebody needs to be held accountable (Tamati, 1992).

There are high costs for schools in pursuing the issue of truancy, although schools such as Avalon Intermediate have, at least for the present, "won" the battle. Yet it is not surprising that many boards see the need to police truancy as a low priority, in relation to their overall duties:

... boards claim they are too busy in their roles as school administrators to have the time to follow up truancy cases. Their priorities for funding lie in areas where a maximum number of children will benefit from their decisions rather than concentrating on a very small number, relatively speaking, and becoming involved in what is seen as a costly, time-consuming, and often ineffective exercise (Donn et al., p. 3).

As well, however, those schools with high rates of truancy will be less able to develop the resources to compete in the new educational market. Here, they are in a double bind. On the one hand, if they put their energies into education, virtually ignoring the problem of truancy (as the above quote suggests), then the school will become unattractive in the market by virtue of being known as a school with a truancy problem. As well, of course, they have a legislative requirement to police 
truancy, and could be held to account by the Minister of Education for not fulfilling that requirement. If, on the other hand, time and resources are put into solving truancy problems, then inevitably the education offered within the school will suffer. This can be seen clearly in a putative job description for a school-based attendance officer, put out by the School Trustees' Association (STA) (1992). This lists the procedures for the attendance officer as follows:

- Patrol, checking for truanting pupils. This includes any primary or secondary pupils.

- Identify truants and, where appropriate, pick them up and return them to school or home.

- Keep a diary record of all contacts, and a file on each pupil dealt with.

- Discuss with pupil's parents the reasons for absence and record this information.

- Communicate with the school about pupil's situation.

- Provide support for persistent truants to help get them to school.

- Liaise with Deputy Principal, Form Teachers, Visiting Teachers.

- Report regularly to Principal, Deputy Principal and Teacher in charge of attendance.

The STA Guide suggests that, if an outside person were employed, the costs to a large secondary school (it does not mention the class or ethnic composition of the school) may be over $\$ 7000$ per year. It is far more likely that schools will use teachers to police truancy, or try and ignore the problem altogether.

Because of the inequalities between schools, and the need to compete in the educational market, the problem of truancy impacts most heavily on schools with large working class, Maori and Pacific Island populations.

\section{Truancy: a social issue}

The findings of various research reports on truancy note the high Maori composition of truants. For example, the Department of Education's 1982 report noted the following:

One feature of the results ... is that in both primary and secondary schools the absence rates for Maori students were higher than those for European students in every absence category (i.e., justified as well as unjustified). In general, Pacific Island students' rates fell between those for the two other groups. The two exceptions occurred for justified absences for parental convenience, where Pacific Islanders' rates were lower than those of both Europeans and Maori, and for unexplained absences, where Pacific Island students had the highest rates of any group (Department of Education, 1982, p. 41).

This report also addressed the question of whether truancy was related to socio-economic position per se, or whether truancy by Maori and Pacific Island students was independent of economic position. The report concluded:

It was found that at both primary and secondary schools there was a relation between socio-economic level and justified and unjustified absence rates, both of which tended to become higher as socioeconomic level became lower. By itself, this result lent some support to the possibility that effects due to ethnic origin could be due to socio-economic factors. However, further analysis showed quite clearly that the differences between the justified and unjustified absence rates of European, Maori and Pacific Island students existed at all socio-economic levels (Department of Education, 1982, p. 30).

However, it should be noted that the measurement of socioeconomic position in this survey was actually a measurement of the school average. In other words, a poor Maori from a working class background who attended a middle class school would, in this survey, be classified as middle class. Nevertheless, the findings are clear enough to suggest that truancy is related both to class and to ethnic factors. There tend to be about the same numbers of female as male truants, but distributed differently. For example, in the fourth form there tends to be a high rate 
of female truancy for Pakeha and Maori girls, whereas fourth form Pacific Island girls have low rates of truancy. For them, truancy increases markedly in the fifth form.

Because truancy tends to be clustered within working class, Maori and Pacific Island groups, this means, in effect, that certain schools face high rates of truancy whilst other schools have very few truants. It is likely that schools with high truancy rates also have other problems, such as relatively low educational achievement and a more diverse student population (this is, of course, only a "problem" when there are inadequate resources to cater for all students effectively). What, then, does the Government's 1992 policy have to offer those schools facing high, and increasing, rates of truancy?

\section{Truancy, parenting and social responsibility}

Unfortunately, the answer to this question is "very little". The policy statement is almost completely concerned with defining the various responsibilities of parents, boards of trustees and the Department of Social Welfare in truancy cases. Indeed, in the first 8 pages of the document plus the introductory letter, the word "responsibility" occurs 20 times.

The following, for example, is an extract from the joint letter from the Ministers of Social Welfare and Education which was attached to 1992 Truancy document:

It is the responsibility of parents to ensure that their school age children are registered at a school and that their attendance is maintained.

Boards of trustees also have a responsibility to record that attendance and take action where it breaks down.

Recent public concern has been reinforced by the findings of the review of the Children, Young Persons and their Families Act. It called on the Government to define the respective responsibilities of those concerned in relation to truancy and absenteeism.

As Ministers of Social Welfare and Education we both recognise the importance of clarifying the responsibilities of boards of trustees and the Department of Social Welfare in this area. The attached protocol clearly lays down who is responsible in certain circumstances.
The Government response to concerns expressed in 1992 is an administrative, not a political one. The policy focuses exclusively on the protocol to be followed by boards of trustees when dealing with a case of truancy. The document notes that the Ministry of Education funds schools through the operational grant to police truancy, but there is no discussion of whether that funding is adequate or fairly distributed. Further, the issue of young truants failing to enrol in school and thus "slipping through the net" is not addressed at all. Indeed, the policy fails to discuss any of the political issues relating to truancy; it is simply an administrative document.

One area the policy does cover is the responsibilities of boards of trustees. These are listed (1992) as follows:

- $\quad$ keep records and identify truants; have a school policy for truancy; follow the policy;

- call on Education resources to address persistent truancy;

- identify when truancy has become a care or protection concern;

- document the care or protection concern; refer to Care and Protection Co-ordinator;

- assist Co-ordinator with convening as requested (i.e., family contacts, information);

- participate in family group conference as "referring agency"; participate in implementing the plan as required in the plan; participate in reviews of the plan, as required.

There are significant problems in the Government's response to the truancy issues of 1992, but such a response is very similar to that in other areas of policy in education and throughout the state. The links between the truancy issue and the state management of education are discussed in the next section. 


\section{The Neo-Liberal State and Truancy Policy}

The implementation of the policy of Tomorrow's Schools has seen an increasing adherence by the state, especially under the National government, to neo-liberal principles of state management, governed by agency and public choice theories, and increasingly by a socially conservative discourse. All these influences can be seen clearly in the truancy issue. First, the responsibility for truancy has been devolved to individual boards of trustees, as the state has shed its responsibilities for school operations. This has nothing to do with where truancy policy is best dealt with, because it is reasonably clear that some kind of umbrella agency, which can trace all New Zealand children throughout school, is the best place. Instead, devolution meets the twin requirements of neo-liberal theory: those of accountability and removing responsibility from the central state.

Second, truancy issues are tending increasingly to be dealt with outside the educational arena; either as a Social Welfare issue of care and control, or as a Police issue relating to public order. Truants are thus seen as either deviant or potentially criminal, rather than as victims of an inadequate education system.

Thirdly, as in other areas of the state, the resources available to meet educational demands, including those of truancy, are slowly declining, and as a result schools are increasingly unable to respond to issues such as truancy. Where, in the past, schools sought educational responses to truancy (however inadequate), now it simply becomes one more burden for them to carry. As was suggested above, it is likely that schools with a range of educational problems - and it is these schools which are most likely to experience high rates of truancy - will simply let truants drop out of school, rather than go through the time-consuming process of trying to deal with the issues involved. Of course, the state could then, under current Education legislation, sack the board of trustees for not complying with the law, but such as response seems unlikely.

It was claimed in the media in 1992 that truancy is on the increase, and there is little doubt, looking at the experience of other countries which have raised the school leaving age, that it will increase further in some schools next year. Yet the resources needed to combat truancy are not increasing; in fact they are decreasing in real terms. This will be an increasing problems for schools which service low socioeconomic areas, or areas with a high Maori population. The state proved during 1992 to be quite willing to allow the gaps between wealthy and poorer schools to increase and truancy, along with the other elements of poverty and alienation, is both cause and effect of this process. There is an urgent need for research on truancy rates in poorer secondary schools, to examine the extent to which resources are being, or need to be, put into this area.

\section{Conclusion}

Truancy has existed in the state schooling system since that system was established. However, the reasons for truancy have altered over time. In order to consider educational responses to truancy in the 1990s, we need to understand why young people play truant from school. The major reason can be summed up as alienation from the processes or goals of schooling. This alienation may be due to low educational achievement; it is no coincidence that the groups who tend to play truant are also those who underachieve at school (Lauder, Hughes and Taberner, 1985; Willis, 1977). Truancy is also one of the possible responses to the increasing breakdown of links between school achievement and job prospects; the other, equally futile, being the increased pursuit of credentials (Nash, 1985; Snook, 1989).

Truancy may also be a response to direct economic conditions. Schooling is no longer free and, indeed, may be very expensive. A recent report on poverty noted that:

If the employment situation improves in the future ... people ... with good education and often a university degree will probably find work and be able to pick up the pieces and thus recover. For people with poor education the future outlook is less hopeful. I met many young students who were unable to sit their School Certificate examinations because, with parents unemployed and family on benefit, there was no money to pay for fees. Schools are faced with cuts in education at a time when large numbers are unable to pay for education fees. Education, like health, is a commodity which must be forfeited to supply food for the table (Council of Christian Social Services, 1992, p. 11).

Finally, the research evidence makes it clear that a high proportion of truants are Maori, and that this cannot be attributed solely to low economic status. As Walker (1985), Smith (1990) and others note, it is 
likely that state schooling is irrelevant for large numbers of Maori students.

The response to truancy outlined by the Ministers of Education and Social Welfare (1992) fails to take into account any of these factors. It assumes that truancy is caused by family deviance, and can thus be solved, if at all, by either remedial or punitive means. It should be clear from the evidence of this paper that such responses cannot work. What is needed is some educational response that will ensure that school is relevant to the needs of all pupils. The many Activity Centres set up around the country in the 1970s and 1980s provide one kind of response; Kura Kaupapa Maori another.

New developments in education, such as the Achievement Initiative, must take into account that a small but significant proportion of the school population rejects both the processes and the outcomes of schooling. In the absence of jobs for young people leaving school, alienation is inevitable. Finally, of real concern is the increasing cost of schooling at a time when the poor are getting poorer. It will be hard to enforce non-attendance if it is caused by an inability to afford schooling. The twin factors of an increasing gap between rich and poor and an apparent gradual withdrawal of state funding from education, undermine the requirement of compulsory education.

Two consequences lead on from this. The first is that, as in other areas, it is boards of trustees who will have to deal with the concurrent decline in funding and increase in truancy. So long as compulsory schooling remains, and it cannot be removed without major problems of political legitimation, it must be enforced by the state. If boards of trustees become unable to cope with truancy in high-risk schools, a further political response will be necessary. The second consequence is that the authoritarian responses to truancy by the state are likely to increase, rather than there being an attempt to offer resources to solve the problem.

What, then, is needed to minimise truancy beyond 1992? For all truancy groups the evident need is for a culturally relevant schooling, which is affordable (essentially this must mean free) and leads to jobs. For Maori, the development of Kura Kaupapa Maori seems the most effective initiative, given the evidence that bicultural units in schools have many shortcomings (Jacques, 1992).
This points to the need for extra resources, not only for Kura Kaupapa Maori but also to provide for the needs of working class and Pacific Island students. Of course, under current policy the resources are unlikely to be forthcoming. The increasing reliance on parents to top up inadequate budgets can only lead to a drop in school attendance amongst those groups most likely to be truant.

The media attention of 1992 was brought about by claims of increasing truancy in a number of regions and schools. The policy response to this problem failed to provide any constructive solutions. We can expect, then, that 1992 will not have seen the end of the truancy problem; before long, it will be back as an issue in the media.

\section{References}

Berwick-Emms, P. Attendance in Primary Schools. Christchurch: Canterbury Education Board, 1986.

Bolger, Rt. Hon. J. Education for Enterprise Conference. Wellington: Parliament Buildings, 1992.

Codd, J and Gordon, L., "School charters: the contractualist state and education policy" in New Zealand Journal of Educational Studies 26, 1, 1991, pp. 21-34.

Council of Christian Social Services Windows on Poverty. NZCCSS, 1992.

Department of Education Absence from School. Wellington: Department of Education, 1982.

Department of Statistics New Zealand Social Trends: Education. Wellington: Department of Statistics, 1991.

Donn, M., Bennie, N. and Kerslake, J. Who's Not Here...? Working towards keeping "absentee students" at school. Wellington: Ministry of Education, 1991.

Gordon, L. "The bulk funding of teachers' salaries" in Manson, H. (ed) New Zealand Annual Review of Education, 1:1991 Wellington: Victoria University of Wellington, Education Department, 1992, pp. 28-58.

Harker, R. "Culture and knowledge in the New Zealand school curriculum" in Delta 29, 1979.

Harker, R. "Schooling and cultural reproduction" in Codd, J., Harker, R. and Nash, R. (eds) Political issues in New Zealand Education. Palmerston North: Dunmore Press, 1985.

Jacques, K. Community Contexts of Maori-English Bilingual Education: A Study of Six South Island Primary School Programmes. Unpublished PhD thesis, University of Canterbury, 1992. 
Lauder, H., Hughes, D. and Taberner, S. "Education, class and inequality in New Zealand: a preliminary report" in Delta 36, 1985, 31-38.

MacDonald, I. Persistent absenteeism in Christchurch Secondary Schools. Christchurch: University of Canterbury, Education Department. 1991.

Marshall, J., Peters, M. and Smith, G. H. "The Business Roundtable and the privatization of education: individualism and the attack on Maori" in Gordon, L. and Codd, J. (eds) Education Policy and the Changing Role of the State. Palmerston North: Delta, 1991.

Middleton, S. "Equity, equality and biculturalism in the restructuring of New Zealand schools: a life-history approach" in Harvard Educational Review, 1992.

Ministers of Education and Social Welfare Truancy - A Detailed Approach. Wellington: Government Printer. 1992.

Ministry of Education Educational Statistics of New Zealand 1991. Wellington, Ministry of Education, 1991.

Nash, R. "Structures of credentialling: the flow from school to work" in Codd, J., Harker, R. and Nash, R (eds) Political Issues in New Zealand Education. Palmerston North: Dunmore Press, 1985.

Research and Statistics Division Statistics on Maori Education 1992. Wellington: Ministry of Education, 1992.

School Trustees' Association STA Guide No. 8: School Attendance and Truancy. Wellington: School Trustees' Association, 1992.

Smith, G. N. "Taha Maori: Pakeha capture" in Codd, J., Harker, R. and Nash, $\mathrm{R}$ (eds) Political Issues in New Zealand Education, Second edition. Palmerston North: Dunmore Press, 1990.

Snook, I. "Inflated expectations, qualifications and job prospects" in set, 1, 2, 1989.

Tamati, A. "How the battle was won" in Evening Post 23 September 1992

Taylor, R. "The missing pupils" in New Zealand Herald 14 March 1992.

Walker, R. "Cultural domination of Taha Maori: the potential for radical transformation" in Codd, J., Harker, R. and Nash, R (eds) Political issues in New Zealand Education. Palmerston North: Dunmore Press, 1985.

Willis, P. Learning to Labour. Aldershot: Gower, 1977.

\section{The author}

Liz Gordon is a Lecturer in Education at the University of Canterbury. Her research interests are in the areas of state theory, education policy and market reforms. 